\title{
MISJE CZOLOWYCH POLSKICH UNIWERSYTETÓW W KONTEKŚCIE ADEKWATNOŚCI DO OPRACOWANIA I WDROŻENIA BALANCED SCORECARD
}

\section{Wstęp}

Balanced Scorecard (BSC) jest narzędziem strategicznej rachunkowości zarządczej, którego zadaniem jest pomiar, ocena i komunikacja dokonań celem przełożenia strategii na działania ${ }^{1}$. W pierwszej fazie rozwoju narzędzie to miało służyć wsparciu realizacji strategii organizacji z wykorzystaniem zestawu mierników ${ }^{2}$, a następnie zostało rozbudowane do poziomu strategicznego systemu zarządzania ${ }^{3}$, jak również narzędzia wykorzystywanego przy zarządzaniu połączeniami spółek ${ }^{4}$.

Mimo tego, że narzędzia zbliżone koncepcyjnie do BSC, jak np. Tableau de Bord, były stosowane powszechnie w przedsiębiorstwach od przełomu XIX i XX w. ${ }^{5}$, to właśnie koncepcja BSC zyskała współcześnie powszechne zastosowanie $\mathrm{w}$ praktyce gospodarczej. Badania przeprowadzone przez Bain and Company wykazały, że w 2007 66\% badanych spółek wdrożyło Balanced Scorecard $^{6}$, co stanowiło osiągnięcie maksymalnego poziomu przez rosnącą tendencję liczby wdrożeń widoczną od 1992 r., gdy koncepcja Balanced Scorecard została po raz pierwszy zaprezentowana na łamach „Harvard Business Review"7. Mimo odnotowania spadku liczby wdrożeń Balanced Scorecard po 2007 r., w 2010 r. BSC było szóstym najpopularniejszym narzędziem zarządzania wykorzystywanym przez menedżerów ${ }^{8}$.

\footnotetext{
* Doktorant, asystent, Katedra Rachunkowości, Wydział Zarządzania, UŁ.

${ }^{1}$ R Kaplan, D. Norton, Strategiczna karta wyników, jak przelożyć strategię na działanie, Wydawnictwo Naukowe PWN, Warszawa 2002, s. 27 i n.

${ }^{2}$ R Kaplan, D. Norton, The Balanced Scorecard: measures that drive performance, „Harvard Business Review" 1992, vol. 70, s. 70-79.

${ }^{3}$ R Kaplan, D. Norton, Using the Balanced Scorecard as a strategic management system, „Harvard Business Review” 1996, vol. 85, iss. 7/8, s. 150-161.

${ }^{4}$ R. Kaplan, D. Norton, B. Rugelsjoen, Managing alliances with the Balanced Scorecard, „Harvard Business Review” 2010, vol. 88, iss. 1/2, s. 114-120.

${ }^{5}$ A. Szychta, Etapy ewolucji i kierunki integracji metod rachunkowości zarządczej, Wydawnictwo UŁ, Łódź 2008, s. 471 i n.

${ }^{6}$ D. Rigby, Executive Guide - Management Tools 2007, Bain \& Company Publishing, 2007.

${ }^{7}$ R. Kaplan, D. Norton, The Balanced Scorecard...

${ }^{8}$ D. Rigby, Management Tools 2011 An Executive's Guide, Bain \& Company Publishing, 2011.
} 
Rosnąca popularność Balanced Scorecard stała się przyczyną zrodzenia poważnych wątpliwości dotyczących rzeczywistego wpływu wdrożeń na efektywność funkcjonowania organizacji ${ }^{9}$, które zaowocowały serią badań mających na celu wykazanie poprawy efektywności funkcjonowania organizacji wdrażających $\mathrm{BSC}^{10}$. Badania te, mimo zastosowania różnych metod badawczych i zbiorów danych, nie dowiodły bezpośredniego wpływu zastosowania BSC na efektywność podmiotów ją wdrażających. Główną przyczyną braku jednoznacznych rezultatów, we wszystkich analizowanych badaniach, były trudności $\mathrm{z}$ ustaleniem wiarygodnych miar efektywności oraz wyodrębnieniem wyłącznego wpływu wdrożenia spośród innych czynników oddziałujących na funkcjonowanie podmiotów.

Postępujący proces globalizacji, niwelacja barier mobilności ludności, w połączeniu z nasilającą się konkurencją między uczelniami wyższymi stały się przyczyną coraz szerszego zainteresowania zastosowaniem nowoczesnych metod zarządzania przez te organizacje, $\mathrm{w}$ tym również $\mathrm{BSC}^{11}$. Zasadniczą barierą przy opracowywaniu i wdrażaniu BSC w uczelniach wyższych, w tym w uniwersytetach, jest specyfika ich funkcjonowania, w szczególności fakt realizacji przezeń celów wszystkich sektorów działalności społeczno-gospodarczej, co znacząco utrudnia adaptację modeli ze świata biznesu i wymaga opracowywania dostosowanych modeli BSC.

Celem niniejszego artykułu jest porównanie misji czołowych polskich uniwersytetów i ocena ich adekwatności do opracowania wizji, przełożenia na strategię i cele strategiczne na potrzeby opracowania i wdrożenia BSC. Artykuł stanowi rozwinięcie rozważań autora prezentowanych w artykule pt. Zastosowanie Balanced Scorecard $w$ uczelniach wyższych - analiza ostatnich wdrożeńn ${ }^{12}$.

${ }^{9}$ Np. D. Oteley, Performance management: a framework for management control systems research, „Management Accounting Research” 1999, no. 10(4), s. 363-382; H. Norreklit, The Balanced Scorecard: what is the score? A rhetorical analisis of the Balanced Scorecard, „Accounting, Organizations and Society” 2003, no. 28(6), s. 591-619; S. Davies, T. Albright, An investigation of the effect of Balanced Scorecard implementation on financial performance, „Management Accounting Research” 2004, no. 15(2), s. 135-153.

${ }^{10} \mathrm{~Np}$. R. Kaplan, D. Norton, Strategy Focused Organization, How Balanced Scorecard Companies Thrieve in The New Business Environment, Harvard Business School Press 2001; F. De Gausser, S. Mooraj, D. Oyon, Does the Balanced Scorecard add value? Empirical evidence on its effect on performance, ,European Accounting Review” 2009, vol. 18, no. 1, s. 93-122.

${ }^{11} \mathrm{~Np}$. O. Chang, C. Chow, The Balanced Scorecard: A potential tool for supporting change and continuous improvement in accounting education, „Issues in Accounting Education” 1999, vol. 14, no. 3, s. 395-412; K. Haddad, Using the Balanced Scorecard for improving finance education, „Financial Practice and Education”, Spring/Summer 1999, s. 92-101; I. Sobańska, A. Szychta, J. Michalak, M. Michalak, Założenia i ogólna struktura projektu systemu rachunkowości zarządczej w Uniwersytecie Łódzkim, „Zeszyty Teoretyczne Rachunkowości” 2007, t. 36 (92).

${ }^{12} \mathrm{~W}$. Kariozen, Zastosowanie Balanced Scorecard w uczelniach wyższych - analiza ostatnich wdrożen, [w:] E Walińska (red.), Zarzadzanie, finanse i rachunkowość wobec wyzwań wspótczesnej gospodarki opartej na wiedzy, Wydawnictwo UŁ, Łódź 2012, s. 25-34. 
Biorąc za punkt wyjścia specyfikę uniwersytetów jako jednostek realizujących zadania charakterystyczne dla wszystkich sektorów działalności społecznogospodarczej, określono znaczenie misji w procesie projektowania BSC oraz przedstawiono wybrane modele tego narzędzia opracowane dla uczelni wyższych. W ostatniej części zaprezentowano wyniki badania porównawczego misji 10 czołowych, polskich uniwersytetów, a następnie oceniono możliwość uwzględnienia zidentyfikowanych założeń misji tych jednostek w ramach modelu BSC opracowanego przez D. Rubena.

\section{Uniwersytet jako specyficzny podmiot funkcjonujący w otoczeniu rynkowym}

Uniwersytety stanowią specyficzną grupę jednostek funkcjonujących w ramach otoczenia społeczno-gospodarczego. Specyfika ta ujawnia się już w momencie próby przyporządkowania uniwersytetów do konkretnego sektora działalności społeczno-gospodarczej. Opierając się na kryteriach formy organizacyjno-prawnej oraz celów prowadzonej działalności, ze względu na występowanie bezpośredniego wpływu celów obranych przez podmiot na przybieraną przezeń formę organizacyjno-prawną, większość organizacji można bez większych wątpliwości przyporządkować do jednego z trzech sektorów obejmujących:

- I - instytucje państwa,

- II - organizacje gospodarcze mające na celu osiąganie zysku,

- III - organizacje non profit.

W przypadku uniwersytetów niezależne zastosowanie kryterium formy organizacyjno-prawnej oraz kryterium celów działalności rodzi poważne wątpliwości co do możliwości zaklasyfikowania tych jednostek do konkretnego sektora.

Analizując zapisy art. 9, pkt 11 ustawy z 27 sierpnia 2009 r. o finansach publicznych $^{13}$, stanowiącego, że sektor finansów publicznych tworzą m.in. uczelnie publiczne, uwzględniając fakt, że wszystkie uniwersytety działające na terytorium Rzeczypospolitej posiadają status uczelni publicznych oraz że jednostki te bez wyjątku posiadają status państwowych osób prawnych, właściwość przypisania uniwersytetów do sektora I nie pozostawia najmniejszych wątpliwości.

Poważne wątpliwości rodzą się w przypadku podjęcia próby klasyfikacji uniwersytetów opartej na kryterium celów działalności. W przypadku publicznych uczelni wyższych nie można mówić o warunkowaniu formy organizacyjno-prawnej przez cele działalności, gdyż nie występuje dowolność wyboru tej

${ }^{13}$ Ustawa z 27 sierpnia 2009 r. o finansach publicznych, Dz.U. 2009, nr 157, poz. 1240, z późn. zm. 
formy. Zgodnie z ustawą z 27 lipca 2005 r. Prawo o szkolnictwie wyższym ${ }^{14}$ utworzenie uczelni publicznej następuje $\mathrm{w}$ drodze ustawy ${ }^{15} \mathrm{i} \mathrm{w}$ momencie powołania jednostka ta zyskuje status państwowej osoby prawnej ${ }^{16}$. Z chwilą powołania każda publiczna uczelnia wyższa jest również zobligowana do realizacji następujących, określonych ustawowo zadań (celów) ${ }^{17}$ :

1) kształcenia studentów w celu zdobywania i uzupełniania wiedzy oraz umiejętności niezbędnych w pracy zawodowej;

2) wychowywania studentów w poczuciu odpowiedzialności za państwo polskie, za umacnianie zasad demokracji i poszanowanie praw człowieka;

3) prowadzenia badań naukowych i prac rozwojowych oraz świadczenia usług badawczych;

4) kształcenia i promowania kadr naukowych;

5) upowszechniania i pomnażania osiągnięć nauki, kultury narodowej i techniki, w tym poprzez gromadzenie i udostępnianie zbiorów bibliotecznych i informacyjnych;

6) prowadzenia studiów podyplomowych, kursów i szkoleń w celu kształcenia nowych umiejętności niezbędnych na rynku pracy w systemie uczenia się przez całe życie;

7) stwarzania warunków do rozwoju kultury fizycznej studentów;

8) działania na rzecz społeczności lokalnych i regionalnych;

9) stwarzania osobom niepełnosprawnym warunków do pełnego udziału w procesie kształcenia i w badaniach naukowych.

Analizując powyższy katalog celów, można zauważyć, że jest on niezwykle szeroki i obejmuje cele charakterystyczne dla organizacji I sektora w formie realizacji polityki rządowej - w postaci kształcenia i wychowywania kolejnych pokoleń pracowników i obywateli; cele charakterystyczne dla jednostek przypisywanych do sektora II, jak choćby świadczenie usług i prowadzenie studiów niefinansowanych z budżetu państwa; jak również cele charakterystyczne dla jednostek III sektora w postaci wspierania osób niepełnosprawnych, czy działania na rzecz społeczności lokalnych. Dodatkowo należy zaznaczyć, że uniwersytety poza realizacją obligatoryjnych celów swojej działalności, prowadzą również inną działalność, o charakterze przedsiębiorczym, jak choćby komercyjny wynajem powierzchni, odpłatna działalność wydawnicza, czy współpraca w zakresie organizacji wydarzeń z pogranicza nauki i biznesu. Taka sytuacja sprawia, że jednoznaczne określenie przyporządkowania uniwersytetów do jednego sektora działalności społeczno-gospodarczej na podstawie kryterium celów działalności jest niemal niemożliwe.

${ }^{14}$ Ustawa z 27 lipca 2005 r. Prawo o szkolnictwie wyższym, Dz.U. 2005, nr 164, poz. 1365, z późn. zm.

${ }^{15}$ Ibidem, art. 18, ust. 1.

${ }^{16}$ Ibidem, art. 12.

${ }^{17}$ Ibidem, art. 13. 
Jak już wspomniano, w większości organizacji obrane przez założycieli ogólne cele warunkują ich formę organizacyjno-prawną i w większości przypadków pozwalają na przyporządkowanie do jednego z trzech sektorów. Sytuacja uniwersytetów jest znacznie bardziej skomplikowana, gdyż obok trudności z przypisaniem ich do konkretnego sektora, są one zobligowane do realizacji ustawowo ustalonych celów, co sprawia że opracowanie założeń strategicznych ich funkcjonowania w postaci wizji, misji i strategii są znacząco utrudnione.

Rosnąca konkurencja między uczelniami zarówno publicznymi, jak i niepublicznymi, krajowymi i zagranicznymi sprawia, że jednostki te funkcjonują $\mathrm{w}$ otoczeniu rynkowym i muszą rywalizować również z niepublicznymi uczelniami, które funkcjonują w sposób charakterystyczny dla II sektora. Dodatkowo rosnące współzawodnictwo między uczelniami publicznymi sprawia, że jednostki te dla utrzymania się na rynku muszą poszukiwać metod pozwalających na poprawę efektywności ich funkcjonowania we wszystkich wymiarach działalności. Jednym z narzędzi o postulowanym, pozytywnym wpływie na funkcjonowanie podmiotów działających w otoczeniu rynkowym jest Balanced Scorecard, jednak ze względu na specyfikę funkcjonowania uniwersytetów nie jest możliwe bezpośrednie przełożenie doświadczeń płynących $\mathrm{z}$ jego wdrożeń $\mathrm{w}$ innych typach jednostek na uniwersytety. Pojawia się konieczność gruntownego przeprojektowania tego narzędzia i dostosowania do specyfiki uniwersytetów. Problemy na poziomie samego projektowania BSC dla uniwersytetów pojawiają się już na pierwszym etapie przełożenia misji i wizji na strategię podmiotu.

\section{Misja uniwersytetu w procesie projektowania Balanced Scorecard}

Pierwszym etapem w procesie konstruowania i wdrażania Balanced Scorecard jest przełożenie wizji organizacji na strategię ${ }^{18}$. Wizja organizacji stanowi jej perspektywiczny obraz oparty na misji i celach długoterminowych ${ }^{19}$, na podstawie czego można wnioskować, że dla właściwego opracowania i wdrożenia BSC konieczne jest opracowanie misji, która pozostając $\mathrm{w}$ zbieżności z celami długookresowymi pozwoli na opracowanie wizji i przełożenie jej na strategię. Misja jednostki planującej wdrożenie BSC powinna więc być jasno określona, tak aby na etapie formułowania strategii nie wystąpiły problemy z jej interpretacją.

${ }^{18}$ R. Kaplan, D. Norton, Putting the Balanced Scorecard to Work, „Harvard Business Review" 1993, vol. 71, iss. 5, s. 134-147; R. Kaplan, D. Norton, Using the Balanced Scorecard as a Strategic Management System, ibidem, 1996, vol. 85, iss. 7/8, s. 150-161.

${ }^{19}$ T. Sztucki, Encyklopedia marketingu, Placet, Warszawa 1998. 
W organizacjach należących do II sektora określenie misji, wizji, celów długoterminowych i przełożenie ich na strategię, pomimo złożoności tego procesu i koniecznych do jego przeprowadzenia nakładów, nie nastręcza większych problemów. Wynika to $\mathrm{z}$ faktu, że organizację nastawione na zysk są w większości zorientowane na dostarczanie wartości właścicielom bądź interesariuszom i mają jasno określone, kwantyfikowalne cele długookresowe. Możliwość zbudowania właściwej strategii, kluczowej dla powodzenia wdrożenia Balanced Scorecar w tej grupie podmiotów została poparta licznymi przykładami z praktyki gospodarczej, spośród których najszerzej opisanymi były wdrożenia w Mobil USM\&R i Rockwater. W Mobil USM\&R oparto strategię na wzroście produktywności $\mathrm{w}$ ramach łańcucha wartości, redukcji kosztów, oraz zwiększaniu sprzedaży ${ }^{20}$, natomiast $\mathrm{w}$ Rockwater kluczowymi składnikami strategii były ciągłe doskonalenie procesów, satysfakcja klientów, oraz wypełnianie oczekiwań interesariuszy ${ }^{21}$.

Organizacje klasyfikowane w ramach III sektora stanowią grupe podmiotów, w których misje są zazwyczaj bardzo precyzyjnie zdefiniowane ze względu na fakt, że $\mathrm{w}$ wielu przypadkach ich realizacja stanowi jedyną przyczynę rozpoczęcia działalności. Ponieważ tego typu jednostki w większości przypadków nie koncentrują się w ramach swojej działalności na generowaniu korzyści finansowych, przełożenie misji, wizji i celów długookresowych na strategię nie stanowi tak znaczącego problemu jak w przypadku uniwersytetów, które nie mogą być przypisane bezpośrednio do jednego sektora działalności społeczno-gospodarczej na podstawie kryterium celów działalności.

Specyfika uniwersytetów, ich formy organizacyjno-prawnej oraz celów działalności, jak również fakt występowania potencjalnej możliwości poprawy ich funkcjonowania poprzez wdrożenie BSC skłania do dogłębnej analizy formułowanych przez te jednostki misji pod kątem ich adekwatności do przełożenia na strategię $\mathrm{w}$ pierwszym stadium projektowania. Aby dokonać takiej oceny konieczne jest również przeanalizowanie dotychczas opracowanych modeli i określenie modelu stanowiącego punkt odniesienia.

\section{Przegląd dotychczasowych wdrożeń Balanced Scorecard w uczelniach wyższych}

Schemat konstrukcyjny Balanced Scorecard opracowany przez twórców koncepcji, R. Kaplana i D. Nortona, obejmuje uwzględnienie czterech podstawowych perspektyw ${ }^{22}$ :

${ }^{20}$ R. Kaplan, D. Norton, Strategy Focused Organization, How Balanced Scorecard Companies Thrieve in The New Business Environment, Harvard Business School Press 2001.

${ }^{21}$ R. Kaplan, D. Norton, Putting the Balanced Scorecard...

${ }^{22}$ R. Kaplan, D. Norton, The Balanced Scorecard... 
1) finansowej,

2) klienta,

3) procesów wewnętrznych,

4) rozwoju.

Oryginalna koncepcja Balanced Scorecard została opracowana dla jednostek nastawionych na zysk, czyli klasyfikowanych do II sektora. W tego typu jednostkach, zgodnie $\mathrm{z}$ założeniami twórców koncepcji, logiczna kolejność projektowania perspektyw powinna być zgodna z porządkiem przedstawionym powyżej ${ }^{23}$. Analiza dotychczasowych wdrożeń w jednostkach II sektora wskazuje, że taka metodologia projektowania perspektyw pozwala na zaprojektowanie narzędzia umożliwiającego wsparcie realizacji strategii, lecz w przypadku uniwersytetów, których specyfika funkcjonowania jest znacznie bardziej skomplikowana niż ma to miejsce w przypadku jednostek II sektora, możliwość opracowania Balanced Scorecard zgodnie z układem zaprojektowanym dla jednostek nastawionych na zysk pozostaje wątpliwa. Analiza literaturowa dotychczasowych wdrożeń Balanced Scorecard w uczelniach wyższych wskazuje, że w praktyce są stosowane dwa podejścia do formułowania perspektyw:

a) bazujące na oryginalnym schemacie konstrukcyjnym,

b) oparte na zmodyfikowanym schemacie konstrukcyjnym.

Jednym z najlepiej opisanych wdrożeń przeprowadzonych z zastosowaniem oryginalnego schematu konstrukcyjnego była implementacja BSC w irańskim Yazd University ${ }^{24}$. Zaprezentowany model został opracowany $\mathrm{z}$ wykorzystaniem czterech perspektyw, w ramach których zastosowano mierniki o wątpliwej adekwatności do pomiaru dokonań uczelni wyższej. Szczególne wątpliwości budzi uwzględnienie w ramach perspektywy finansowej jedynie wskaźników opartych na kosztach i przychodach, jak również zastosowanie wskaźnika liczby publikacji jako jedynej podstawy pomiaru dokonań naukowych jednostki.

Uwzględniając złożoność uczelni wyższych pod względem mnogości wykorzystywanych źródeł finansowania, zastosowanie klasycznych, prostych miar finansowych nie powinno stanowić jedynej podstawy ich oceny. Nieuwzględnienie w modelu mierników opisujących inną niż biznesowa działalność jednostki, nawet w przypadku uczelni prywatnych, takich jak wskaźniki poziomu finansowania grantami i dotacjami, poziom wydatków na aparaturę badawczą i tym podobne, stanowi znaczące zubożenie modelu i budzi poważną wątpliwość, czy tak zaprojektowany model może w efektywny sposób mierzyć dokonania jednostki i wspierać realizację jej strategii.

${ }^{23}$ R. Kaplan, D. Norton, Strategy Focused Organization...

${ }^{24}$ D. Farid, M. Nejati, H. Mirfakhredini, Balanced Scorecard application in universities and higher education institutes: Implementation guide in iranian context, „Annals of University of Bucharest" 2008, Economic and Administrative Series, no. 2, s. 31-45; D. Farid, M. Nejati, H. Mirfakhredini, Prioritizing higher education Balanced Scorecard performance indicators using fuzzy approach in an iranian context, ,Lex et Scientia” 2008, vol. 15, iss. 2, s. 338-349. 
Kolejną wątpliwością dotyczącą konstrukcji perspektyw i uwzględnionych w ich ramach mierników jest możliwość pomiaru dokonań naukowych jednostki jedynie opierając się na średniej liczbie prac opublikowanych w ciągu roku ${ }^{25}$. Nieuwzględnienie podstawowych miar działalności naukowo-badawczej, jak choćby liczby cytowań, czynnego udziału w konferencjach naukowych, ilości wdrożonych rozwiązań biznesowych, czy zgłoszonych patentów sprawia, że również $\mathrm{w}$ tym zakresie omawiany model wydaje się być zbyt ograniczony dla efektywnego wsparcia funkcjonowania systemu zarządzania jednostką.

$\mathrm{Na}$ podstawie analizy irańskiego modelu można stwierdzić, że opisywana BSC została zaprojektowana w sposób charakterystyczny dla jednostek II sektora, co spowodowało pominięcie wielu istotnych aspektów funkcjonowania uczelni wyższej. Koncentracja na perspektywie finansowej, jak również brak wyodrębnienia obszarów działalności związanej z kształceniem studentów i prowadzeniem badań naukowych wpłynęły zapewne na nieuwzględnienie wielu istotnych z punktu widzenia BSC mierników i w konsekwencji na wątpliwą adekwatność modelu do wsparcia funkcjonowania uczelni wyższej. Opisywany przypadek wskazuje wątpliwości co do możliwości zastosowania niezmodyfikowanej konstrukcyjnie BSC w uczelniach wyższych, co znalazło również swoje odzwierciedlenie w pracach innych badaczy ${ }^{26}$.

Jednym z najszerzej opisywanych w literaturze przedmiotu wdrożeń BSC opartej na zmodyfikowanych założeniach konstrukcyjnych był przypadek Uniwersytetu Wisconsin-Stout ${ }^{27}$, dla którego opracowano Balanced Scorecard z wykorzystaniem pięciu perspektyw ${ }^{28}$ :

a) kształcenia,

b) studentów,

c) budżetowo-finansowej,

d) wykładowców i innych pracowników,

e) efektywności funkcjonowania.

Analiza układu perspektyw oraz uwzględnionych w ich ramach mierników pozwala stwierdzić, że odejście od oryginalnych założeń konstrukcyjnych przyczyniło się do lepszego dopasowania modelu do potrzeb pomiaru dokonań w uniwersytecie. Potwierdzeniem tego przypuszczenia może być fakt, że po wdrożeniu BSC Uniwersytet Wisconsin-Stout, otrzymał prestiżową nagrodę Baldrige Education Award w 2001 r. $^{29}$

${ }^{25}$ D. Farid, M. Nejati, H. Mirfakhredini, Prioritizing higher education...

${ }^{26} \mathrm{~Np}$. B. Ruben, Toward a balanced scorecard for higher education: rethinking the college and university excellence indicators framework, „Higher Education Forum QCI Center for Organizational Development and Lidership" 1999, no. 99(02), s. 1-10.

${ }^{27}$ D. Beard, Successful applications of the Balanced Scorecard in higher education, ,,Journal of Education for Business", May/June 2009, s. 275-282; D. Karathanos, P. Karathanos, Applying the Balanced Scorecard to education, ibidem, 2005, vol. 80, no. 4, s. 222-230.

${ }^{28}$ D. Karathanos, P. Karathanos, Applying...

${ }^{29}$ Ibidem. 
Pomimo uznania analizowanego wdrożenia $\mathrm{z}$ wysoce skuteczne ${ }^{30}$, brak uwzględnienia w ramach omawianego schematu konstrukcyjnego perspektywy naukowo-badawczej może stanowić poważną barierę w jego stosowalności w jednostkach innych niż uczelnie wyższe zajmujące się jedynie kształceniem studentów. Zbliżony do omawianego, lecz obejmujący perspektywę naukowo-badawczą, model zaproponował D. Ruben. Model ten uwzględnia pięć perspektyw ${ }^{31}$ :

a) kształcenia,

b) naukowo-badawczą,

c) jakości i zasięgu usług,

d) satysfakcji pracowników,

e) finansową.

Zaprezentowany zestaw perspektyw, jak również dobrane $\mathrm{w}$ ich ramach mierniki składają się na model BSC o najwyższym stopniu dopasowania do specyfiki funkcjonowania uczelni wyższych spośród analizowanych modeli.

W ramach perspektywy kształcenia D. Ruben opracował zestaw mierników obejmujących efekty na poziomie programów, przedmiotów i studentów, w perspektywie badawczej - miary wpływu naukowego badań, w ramach perspektywy jakości i zasięgu usług - miary zadowolenia interesariuszy,

w perspektywie satysfakcji pracowników - mierniki satysfakcji pracowników naukowych i obsługi, natomiast w perspektywie finansowej - miary oparte na przychodach i kosztach ${ }^{32}$. Mimo, że skuteczność opisywanego modelu nie została zweryfikowana empirycznie, to na podstawie samej analizy jego konstrukcji można stwierdzić, że spośród modeli BSC prezentowanych w literaturze przedmiotu jest on najlepiej dostosowany do wspierania realizacji strategii i pomiaru dokonań w uczelniach wyższych.

Przeprowadzona analiza wybranych modeli opracowanych na potrzeby uczelni wyższych wskazuje, że ze względu na specyfikę tej grupy podmiotów rozwiązaniem o potencjalnie lepszym dopasowaniu do ich specyfiki jest opacie konstrukcji BSC na zmodyfikowanych schematach konstrukcyjnych. Biorąc pod uwagę fakt, że oryginalna koncepcja BSC została opracowana na potrzeby jednostek klasyfikowanych do II sektora, jej zastosowanie w uczelniach wyższych, w tym w uniwersytetach, budzi znaczne wątpliwości, w szczególności w zakresie koncentracji na perspektywie finansowej i możliwych trudnościach $\mathrm{z}$ przypisaniem mierników związanych $\mathrm{z}$ realizacją procesów kształcenia i naukowo-badawczych w ramach oryginalnych czterech perspektyw.

Dążąc do przeprowadzenia oceny adekwatności misji czołowych polskich uniwersytetów do opracowania strategii na potrzeby wdrożenia BSC, konieczne

\footnotetext{
${ }^{30}$ D. Beard, Successful Applications...; D. Karathanos, P. Karathanos, Applying...

${ }^{31}$ B. Ruben, Toward a balanced scorecard...

${ }^{32}$ Ibidem.
} 
jest określenie modelu stanowiącego punkt odniesienia do analizy. Biorąc pod uwagę rezultaty studiów literaturowych i potencjał poszczególnych modeli, autor niniejszego opracowania uznał za najwłaściwsze przeprowadzenie analizy z wykorzystaniem założeń konstrukcyjnych zaproponowanych przez D. Rubena.

\section{Badanie zalożeń misji czołowych polskich uniwersytetów w kontekście adekwatności do opracowania strategii dla potrzeb wdrożenia Balanced Scorecard}

\subsection{Ogólna charakterystyka badania}

Celem przeprowadzonego badania było dokonanie analizy porównawczej misji dziesięciu czołowych, polskich uniwersytetów przyjętych na mocy uchwał ich senatów oraz określenie ich adekwatności do opracowania strategii na potrzeby wdrożenia BSC w tych jednostkach. Ze względu na złożony charakter postawionego celu, badanie zostało podzielone na trzy zasadnicze fazy. W ramach fazy pierwszej wyodrębniono spośród wszystkich publicznych uczelni akademickich 10 czołowych uniwersytetów, opierając się na wynikach światowych rankingów. Faza druga obejmowała zgromadzenie, selekcję i kontrolę kompletności uchwał senatów wytypowanych w fazie pierwszej jednostek, które stanowiły podstawę analizy przeprowadzonej w fazie trzeciej uwzględniającej zestawienie pozyskanych danych oraz krytyczną ocenę ich adekwatności do opracowania strategii na potrzeby wdrożenia Balanced Scorecard.

\subsection{Faza doboru podmiotów do badania}

Celem fazy doboru podmiotów do badania było wyselekcjonowanie 10 czołowych publicznych uniwersytetów w Polsce, mających stanowić zbiorowość poddaną badaniu $\mathrm{w}$ fazie analizy zgromadzonych danych. Realizacja celu została podzielona na dwie fazy.

W pierwszym stadium wyselekcjonowano wszystkie uniwersytety spośród publicznych uczelni akademickich nadzorowanych przez ministra właściwego ds. szkolnictwa wyższego, opierając się na danych zawartych na stronach internetowych Ministerstwa Nauki i Szkolnictwa Wyższego. W rezultacie fazy pierwszej zidentyfikowano 18 uniwersytetów, które zostały zakwalifikowane do stadium II.

Stadium II fazy doboru podmiotów do badania miało na celu wybór 10 czołowych, polskich uniwersytetów spośród 18 wyselekcjonowanych w stadium I. Dla zachowania jak największej dozy obiektywizmu oceny dokonano na pod- 
stawie corocznych SCIMAGO Institutions Rankings za lata 2010-2012. Na podstawie wstępnej analizy ustalono, że spośród 18 uniwersytetów jedynie 14 zostało sklasyfikowanych, zaś pozostałe 4 nie spełniły minimalnych kryteriów. Następnie przeanalizowano pozycje sklasyfikowanych uniwersytetów wybierając dziesięć, które uzyskały najwyższe miejsca. Lista tych jednostek wraz z ich pozycjami rankingowymi w latach 2010-2012 została przedstawiona w tabeli 1.

Tabela 1. Wykaz dziesięciu polskich uniwersytetów najwyżej sklasyfikowanych w SCIMAGO Institutions Rankings w latach 2010-2012

\begin{tabular}{|c|l|l|r|r|c|}
\hline \multirow{2}{*}{ Lp. Jednostka } & \multirow{2}{*}{ Oznaczenie } & \multicolumn{3}{|c|}{ Pozycja w rankingu } \\
\cline { 5 - 7 } & & & 2010 & 2011 & $\mathbf{2 0 1 2}$ \\
\hline 1. & Uniwersytet Jagielloński w Krakowie & UJ & 362 & 363 & $\mathbf{3 8 3}$ \\
\hline 2. & Uniwersytet Warszawski & UW & 446 & 490 & $\mathbf{5 3 4}$ \\
\hline 3. & $\begin{array}{l}\text { Uniwersytet im. Adama Mickiewicza } \\
\text { w Poznaniu }\end{array}$ & UAM & 2020 & 745 & $\mathbf{7 9 0}$ \\
\hline 4. & $\begin{array}{l}\text { Uniwersytet Mikołaja Kopernika } \\
\text { w Toruniu }\end{array}$ & UMK & 1073 & 819 & $\mathbf{8 6 3}$ \\
\hline 5. & Uniwersytet Wrocławski & UWR & 778 & 873 & $\mathbf{9 2 8}$ \\
\hline 6. & Uniwersytet Śląski w Katowicach & UŚn & 893 & 998 & $\mathbf{1 0 7 5}$ \\
\hline 7. & $\begin{array}{l}\text { Uniwersytet Marii Curie-Skłodowskiej } \\
\text { w Lublinie }\end{array}$ & UMCS & 1142 & 1190 & $\mathbf{1 3 0 0}$ \\
\hline 8. & Uniwersytet Łódzki & UŁ & 1214 & 1258 & $\mathbf{1 4 0 8}$ \\
\hline 9. & Uniwersytet Gdański & UG & 1324 & 1422 & $\mathbf{1 4 7 2}$ \\
\hline 10. & $\begin{array}{l}\text { Uniwersytet Warmińsko-Mazurski } \\
\text { w Olsztynie }\end{array}$ & UWM & 1700 & 1710 & $\mathbf{1 6 2 5}$ \\
\hline
\end{tabular}

Źródło: opracowanie własne na podstawie rankingów SCIMAGO Institution Rankings za lata $2010-2012$.

Analiza wykazała, że w badanym okresie wszystkie wytypowane uniwersytety stanowiły 10 najwyżej sklasyfikowanych $\mathrm{w}$ omawianych rankingach polskich uniwersytetów, jednak w poszczególnych latach ich pozycje rankingowe były różne. Biorąc pod uwagę zwiększoną istotność danych najaktualniejszych, w dalszej części badania analizowane jednostki zostały wykazywane zgodnie z kolejnością odnoszącą się do listy rankingowej z 2012 r., z uwzględnieniem oznaczeń wskazanych w tabeli 1.

W rezultacie fazy doboru podmiotów do badania ustalono listę 10 czołowych, polskich uniwersytetów, dla których w kolejnych fazach badania zgromadzono niezbędne dane i dokonano ich analizy. 


\subsection{Faza gromadzenia danych}

Celem fazy gromadzenia danych było skompletowanie zbioru dokumentów przyjętych na mocy uchwał senatów wytypowanych w fazie doboru podmiotów uniwersytetów, określających misje tych podmiotów. W rezultacie omawianej fazy zebrano pełny zbiór regulacji, które zostały wyszczególnione w tabeli 2 .

Tabela 2. Wykaz dokumentów określających misje uniwersytetów wytypowanych do badania

\begin{tabular}{|l|l|}
\hline \multicolumn{1}{|c|}{ Podmiot } & \multicolumn{1}{|c|}{ Dokument określający misję podmiotu } \\
\hline UJ & Program rozwoju UJ 2012 \\
\hline UW & Uchwała nr 34 Senatu UW z 17 grudnia 2008 r. \\
\hline UAM & Strategia rozwoju UAM na lata 2009-2019 \\
\hline UMK & Strategia rozwoju UMK na lata 2011-2020 \\
\hline UWR & Strategia rozwoju UWR na lata 2009-2015 \\
\hline UŚ & Uchwała Senatu UŚ z 20 maja 1997 r. \\
\hline UMCS & Misja, wizja oraz cele strategiczne i operacyjne UMSC 2011 \\
\hline UŁ & Uchwała nr 141 UŁ z 23 listopada 2009 r. \\
\hline UG & Strategia rozwoju UG do roku 2020 \\
\hline UWM & Program rozwoju UWM w latach 2012-2020 \\
\hline
\end{tabular}

Źródło: opracowanie własne.

\subsection{Faza analizy zgromadzonych danych i oceny rezultatów badania}

W ramach fazy analizy zgromadzonych danych i oceny rezultatów za główny cel postawiono zbadanie adekwatności misji dziesięciu czołowych polskich uniwersytetów do przełożenia na strategię dla potrzeb wdrażania Balanced Scorecard. Cel badania został osiągnięty poprzez realizację dwóch etapów badania.

W ramach realizacji etapu pierwszego zestawiono podstawowe założenia misji analizowanych podmiotów oraz wykonano analizę stopnia złożoności misji pod względem liczby założeń oraz powszechności występowania poszczególnych założeń w ramach badanej grupy podmiotów. Rezultaty etapu pierwszego zostały przedstawione $\mathrm{w}$ tabeli 3 .

Analizując wyniki badania zaprezentowane w tabeli 3, można stwierdzić, że w misjach $70 \%$ badanych jednostek wystąpiły minimum 4 spośród 8 zidentyfikowanych ogólnych założeń. W 90\% jednostek w ramach misji uwzględniono założenie syntezy założeń uniwersalnych i lokalnych, w $60 \%$ odwołanie do tradycji, a w 50\% odwołania do ideałów jedności nauki i nauczania, prawdy i wolności oraz kształtowania elit. Uzyskane rezultaty pozwalają na wnioskowanie, 
Tabela 3. Podstawowe założenia uwzględnione w misjach czołowych polskich uniwersytetów

\begin{tabular}{|l|c|c|c|c|c|c|c|c|c|c|c|}
\hline \multirow{2}{*}{ Założenie misji } & \multicolumn{7}{|c|}{ Jednostka } & \\
\cline { 2 - 15 } & UJ & UW & UAM & UMK & UWR & UŚ & UMCS & UŁ & UG & UWM & $\begin{array}{c}\text { Liczba } \\
\text { wystąpień }\end{array}$ \\
\hline $\begin{array}{l}\text { Synteza wartości uniwer- } \\
\text { salnych i lokalnych }\end{array}$ & $1 *$ & 1 & $1 *$ & $1 *$ & $1 *$ & 1 & 1 & 1 & $1 *$ & 9 \\
\hline Odwołanie do tradycji & 1 & 1 & 1 & 1 & 1 & & & 1 & & 6 \\
\hline Jedność nauki i nauczania & $1 *$ & 1 & $1 *$ & & & & $1 *$ & & $1 *$ & 5 \\
\hline Prawda i wolność & $1^{*}$ & & & $1 *$ & 1 & 1 & & 1 & & 5 \\
\hline Kształtowanie elit & & 1 & 1 & & & $1 *$ & & 1 & $1 *$ & & 5 \\
\hline $\begin{array}{l}\text { Kształtowanie dziedzictwa } \\
\text { kulturowego }\end{array}$ & & & 1 & & $1 *$ & 1 & & & & 1 & 4 \\
\hline $\begin{array}{l}\text { Zapewnienie dostępu do } \\
\text { wiedzy }\end{array}$ & & 1 & & 1 & & & & & $1 *$ & & 3 \\
\hline Otwartość i tolerancyjność & & & & & 1 & & & 1 & & 2 \\
\hline Liczba założeń & 4 & 5 & 5 & 4 & 5 & 4 & 2 & 5 & 2 & 3 & X \\
\hline
\end{tabular}

Uwaga: Ze względu na występowanie znaczących rozbieżności w sposobach formułowania misji w poszczególnych jednostkach, mając na celu zachowanie przejrzystości opracowania oraz jego ogólny charakter, autor dokonał grupowania podobnych założeń. Dla uzyskania pełnego obrazu różnic między założeniami konieczne jest odwołanie się do dokumentów określających misje we wszystkich przypadkach, dla których występowanie założenia zostało oznaczone „,".

Źródło: opracowanie własne na podstawie dokumentacji wyszczególnionej w tabeli 2.

że w grupie czołowych polskich uniwersytetów występuje dość znaczna zbieżność ogólnych założeń misji, przy jednoczesnym zachowaniu ich zwięzłości. Należy jednak zaznaczyć, że w przypadku części z badanych jednostek założenia charakterystyczne dla misji są ujmowane w ramach wizji bądź w katalogu celów strategicznych, co może świadczyć o dość płynnej granicy w interpretacji tych pojęć przejawianej przez zespoły odpowiedzialne za ich opracowanie. Zbieżność misji analizowanych podmiotów można interpretować pozytywnie w kontekście możliwości opracowania uniwersalnego modelu BSC dla tych jednostek, który po każdorazowym dostosowaniu mógłby służyć do wspierania realizacji strategii i pomiaru dokonań tych jednostek.

Etap drugi badania obejmował analizę zidentyfikowanych w ramach etapu pierwszego założeń pod kątem teoretycznej możliwości przełożenia na strategię i przypisania opracowanych na ich podstawie celów strategicznych do perspektyw uwzględnionych w modelu BSC opracowanym przez D. Rubena, stosując następujące oznaczenia:

- $\mathrm{K}$ - perspektywa kształcenia,

- NB - perspektywa naukowo-badawcza, 
- JZU - perspektywa jakości i zasięgu usług,

- SP - perspektywa satysfakcji pracowników,

- F-perspektywa finansowa,

- X-brak możliwości przypisania perspektywy.

Rezultaty etapu drugiego ujęto w tabeli 4.

Tabela 4. Założenia misji czołowych Polskich uniwersytetów w kontekście teoretycznej możliwości ujęcia w modelu BSC D. Rubena

\begin{tabular}{|l|c|}
\hline \multicolumn{1}{|c|}{ Założenie misji } & Perspektywa \\
\hline Synteza wartości uniwersalnych i lokalnych & $\mathrm{X}$ \\
\hline Odwołanie do tradycji & $\mathrm{X}$ \\
\hline Jedność nauki i nauczania & $\mathrm{K} / \mathrm{NB}$ \\
\hline Prawda i wolność & $\mathrm{X}$ \\
\hline Kształtowanie elit & $\mathrm{K}$ \\
\hline Kształtowanie dziedzictwa kulturowego & $\mathrm{NB}$ \\
\hline Zapewnienie dostępu do wiedzy & $\mathrm{K} / \mathrm{NB} / \mathrm{JU}$ \\
\hline Otwartość i tolerancyjność & $\mathrm{JU} / \mathrm{SP}$ \\
\hline
\end{tabular}

Źródło: opracowanie własne.

Przeprowadzone w ramach etapów pierwszego i drugiego analizy wskazują, że trzy spośród pięciu najczęściej występujących założeń misji badanych uniwersytetów mogą powodować trudności w przełożeniu ich na wizję, strategię, cele strategiczne, przypisanie do perspektyw i analizę zmian za pomocą mierników w ramach modelu D. Rubena. Taka sytuacja wynika w znacznej mierze z faktu, że założenia te wykazują znaczny stopień ogólności i zostały oparte na szczytnych, choć trudno kwantyfikowalnych ideałach. Pozostałe pięć założeń, choć znacznie rzadziej występujących, wykazuje teoretyczną możliwość ujęcia w modelu.

Na podstawie przeprowadzonych analiz można stwierdzić, że misje badanej grupy uniwersytetów zostały opracowane w dość jednolity sposób i uwzględniają zbliżone założenia. Za wyjątkiem trzech jednostek uwzględniają również podobną liczbę założeń. Analiza teoretycznej adekwatności założeń misji do opracowania i wdrożenia BSC wzorowanego na modelu D. Rubena w tych jednostkach wykazała, że w zakresie badanego parametru istnieje teoretyczna możliwość opracowania ogólnego modelu BSC dla tych jednostek, który po odpowiednim dostosowaniu miałby szansę na wdrożenie. 


\section{Zakończenie}

Rosnąca popularność Balanced Scorecard jako narzędzia wspierającego realizację strategii oraz służącego do pomiaru dokonań jednostek gospodarczych ${ }^{35}$, $\mathrm{w}$ połączeniu $\mathrm{z}$ coraz silniejszą konkurencją na rynku szkolnictwa wyższego w Polsce i na świecie stały się przyczyną zainteresowania uczelni wyższych jego zastosowaniem. Pomimo znacznej liczby opracowań z zakresu projektowania i wdrażania BSC w jednostkach nastawionych na zysk, ze względu na specyfikę uczelni wyższych, bezpośrednie przełożenie założeń konstrukcyjnych BSC projektowanych dla jednostek II sektora nie wydaje się możliwe.

Taki stan rzeczy stał się przyczyną opracowania licznych modeli BSC dostosowanych do specyfiki funkcjonowania uczelni wyższych, które zależnie od przyjętych założeń, wykazują $\mathrm{w}$ różny stopień teoretycznej adekwatności do zastosowania w uczelniach wyższych. Analizując wybrane modele BSC opracowane dla uczelni wyższej, można stwierdzić, że znacznie większy stopień dopasowania do specyfiki uczelni, w tym w szczególności uniwersytetów, wykazują modele oparte na zmodyfikowanych schematach konstrukcyjnych.

Biorąc pod uwagę metodykę opracowywania BSC, pierwszym etapem, kluczowym dla właściwego zaprojektowania tego narzędzia, jest przełożenie misji i wizji jednostki na strategię i cele strategiczne, które po przypisaniu do perspektyw są opisywane $\mathrm{z}$ wykorzystaniem dostosowanych mierników. Biorąc pod uwagę znaczenie misji uniwersytetów oraz ich specyfikę, pierwszy etap projektowania BSC wydaje się być największym wyzwaniem stojącym przed jednostkami podejmującymi próbę wdrożenia tego narzędzia.

Przeprowadzone przez autora badanie wykazało, że w grupie analizowanych dziesięciu czołowych polskich uniwersytetów występuje znaczny stopień zbieżności podstawowych założeń ich misji, co może wskazywać potencjalną możliwość opracowania jednego, ogólnego modelu BSC dla tych jednostek. Analiza najczęściej występujących założeń misji pod kątem możliwości ich ujęcia w strategii i przypisania do perspektyw w ramach modelu BSC opracowanego przez D. Rubena wykazała, ze najpowszechniej występujące założenia mogą powodować trudności $\mathrm{z}$ przełożeniem na strategię, ujęciem $\mathrm{w}$ ramach perspektyw i opisaniem z wykorzystaniem mierników, głównie z uwagi na ich duży stopień ogólności i oparcie na szczytnych choć trudno kwantyfikowanych ideałach. Na podstawie przeprowadzonych analiz możliwe jest stwierdzenie, że istnieje teoretyczna możliwość opracowania modelu BSC dla analizowanych jednostek, pomimo możliwości wystąpienia trudności już na pierwszym etapie projektowania modelu.

${ }^{35}$ D. Rigby, Executive Guide... 


\section{Literatura}

Beard D., Successful applications of the balanced scorecard in higher education, „Journal of Education for Business", May/June 2009.

Chang O., Chow C., The Balanced Scorecard: A potential tool for supporting change and continuous improvement in accounting education, „Issues in Accounting Education” 1999, vol. 14, no. 3.

Davies S., Albright T., An investigation of the effect of Balanced Scorecard implementation on financial performance, ,Management Accounting Research” 2004, vol. 15(2).

Farid D., Nejati M., Mirfakhredini H., Balanced Scorecard application in universities and higher education institutes: Implementation guide in iranian context, „Annals of University of Bucharest" 2008, Economic and Administrative Series, no. 2.

Farid D., Nejati M., Mirfakhredini H., Prioritizing higher education Balanced Scorecard performance indicators using fuzzy approachin an iranian context, „Lex et Scientia” 2008, vol. 15, iss. 2.

Gausser De F., Mooraj S., Oyon D., Does the Balanced Scorecard add value? Empirical evidence on its effect on performance, „European Accounting Review” 2009, vol. 18, No. 1.

Haddad K., Using the Balanced Scorecard for improving finance education, „Financial Practice and Education", Spring/Summer 1999.

Kaplan R., Norton, D., The Balanced Scorecard: Measures that drive performance, „Harvard Business Review" 1992, vol. 70.

Kaplan R., Norton, D., Putting the Balanced Scorecard to work, „Harvard Business Review” 1993, vol. 71, iss. 5.

Kaplan, R., Norton, D., Using the Balanced Scorecard as a strategic management system, „Harvard Business Review” 1996, vol. 85, iss. 7/8.

Kaplan R., Norton D., Strategy Focused Organization, How Balanced Scorecard Companies Thrieve in The New Business Environment, Harvard Business School Press 2001.

Kaplan R., Norton, D., Strategiczna karta wyników, jak przełożyć strategię na działanie, Wydawnictwo Naukowe PWN, Warszawa 2002.

Kaplan R, Norton, D., Rugelsjoen, B., Managing Alliances with the Balanced Scorecard, „Harvard Business Review” 2010, vol. 88, iss. 1/2.

Karathanos D., Karathanos P., Applying the Balanced Scorecard to education, „Journal of Education for Business" 2005, vol. 80, no. 4.

Kariozen, W., The influence of Balanced Scorecard implementation on the value of oil companyThe case of mobil corporation, „Ad Alta: Journal of Interdisciplinary Research” 2011, vol. 1, iss. 2.

Kariozen W., Zastosowanie Balanced Scorecard w uczelniach wyższych - analiza ostatnich wdrożeń, [w:] E Walińska (red.), Zarzadzanie, finanse i rachunkowość wobec wyzwań współczesnej gospodarki opartej na wiedzy, Wydawnictwo UŁ, Łódź 2012.

Kettunen J., The strategic evaluation of regional development in higher education, „Assessment \& Evaluation in Higher Education" 2004, vol. 29, no. 3.

Lawrence S., Sharma, U., Commodification of education and academic labor-using the balanced scorecard in a university setting, „Critical Perspectives on Accounting” 2002, no. 13.

Liao S.-K., Chen S.-F., Evidence-Based Study on Performance Evaluation of Social Education Institutions with Balanced Scorecard, ,Journal of Social Sciences” 2010, vol. 6 (3).

Michalak J., Pomiar dokonań od wyniku finansowego do Balanced Scorecard, Difin, Warszawa 2008.

Norreklit H., The Balanced Scorecard: what is the score? A rhetorical analisis of the Balanced Scorecard, „Accounting, Organizations and Society“ 2003, No. 28(6). 
Oteley D., Performance management: a framework for management control systems research, „Management Accounting Research“" 1999, no. 10(4).

Program Rozwoju Uniwersytetu Jagiellońskiego 2012 wersja jednolita po nowelizacji Programu Rozwoju Uniwersytetu Jagiellońskiego 2007 przez Senat UJ w czerwcu 2010 r. oraz czerwcu $2012 r$.

Rigby D., Executive Guide - Management Tools 2007, Bain \& Company Publishing, 2007.

Rigby D., Management Tools 2011 An Executive's Guide, Bain \& Company Publishing, 2011.

Ruben B., Toward a balanced scorecard for higher education: rethinking the college and university excellence indicators framework, ,Higher Education Forum QCI Center for Organizational Development and Lidership" 1999, no. 99(02).

SCImago Research Group, 2012. SIR World Report [on-line], http://www.scimagoir.com/ pdf/sir_2012_world_report.pdf.

SCImago Research Group, 2011. SIR World Report [on-line], http://www.scimagoir.com/ pdf/sir_2011_world_report.pdf.

SCImago Research Group, 2010. SIR World Report [on-line], http://www.scimagoir.com/ pdf/sir_2010_world_report.pdf.

Sobańska I., Szychta A., Michalak J., Michalak M., Założenia i ogólna struktura projektu systemu rachunkowości zarządczej w Uniwersytecie Łódzkim, „Zeszyty Teoretyczne Rachunkowości” 2007, t. 36 (92).

Strategia rozwoju Uniwersytetu im. Adama Mickiewicza w Poznaniu, Poznań 2009.

Strategia rozwoju Uniwersytetu Mikołaja Kopernika na lata 2011-2020, Toruń-BydgoszczGrudziądz.

Strategia rozwoju Uniwersytetu Ślaskiego w Katowicach na lata 2012-2020, Katowice.

Sztucki T., Encyklopedia marketingu, Placet, Warszawa 1998.

Szychta A., Etapy ewolucji i kierunki integracji metod rachunkowości zarządczej, Wydawnictwo UŁ, Łódź 2008.

Uchwała nr 34 Senatu Uniwersytetu Warszawskiego z dnia 17 grudnia 2008 r. w sprawie strategii Uniwersytetu Warszawskiego.

Uchwała nr 141 Senatu Uniwersytetu Łódzkiego podjęta na 12 roboczym posiedzeniu z dnia 23.11.2009 w sprawie: misji i strategii UŁ.

Uchwała Senatu Uniwersytetu Gdańskiego nr 9/11 z dnia 24 lutego 2011 roku w sprawie uzupełnienia Strategii Rozwoju Uniwersytetu Gdańskiego.

Ustawa z dnia 27 sierpnia 2009 r. o finansach publicznych, Dz.U. 2009, nr 157, poz. 1240, z późn. $\mathrm{zm}$.

Ustawa z dnia 27 lipca 2005 r. Prawo o szkolnictwie wyższym, Dz.U. 2005, nr 164, poz. 1365, z późn. zm.

Wu H.-Y., Lin Y.-K., Chang C.-H., Performance evaluation of extension education centers in universities based on the balanced scorecard, „Evaluation and Program Planning” 2011, no. 34.

\section{Streszczenie}

Celem niniejszego artykułu jest porównanie misji czołowych polskich uniwersytetów i ocena ich adekwatności do opracowania wizji, przełożenia na strategię i cele strategiczne dla potrzeb opracowania i wdrożenia BSC. Poprzez analizę specyfiki uniwersytetów, znaczenie misji w procesie projektowania BSC oraz analizę schematów konstrukcyjnych BSC uczelni wyższych wybrano model odniesienia i oceniono misje czołowych polskich uniwersytetów pod kątem adekwatności do opracowania i wdrożenia BSC. 


\section{Summary}

\section{MISSIONS OF TOP RANKED POLISH UNIVERSITIES IN CONTEXT OF ITS ADEQUACY TO DEVELOP AND IMPLEMENT BALANCED SCORECARD}

The purpose of this paper is to compare the missions of leading Polish universities and assess their adequacy to develop a vision, translate it into strategy and strategic objectives for the development and implementation of the BSC. By analyzing the specific features of universities, the importance of mission in design implementation of BSC, and characterizing BSC construction schemes in higher education institutions, the author analyses missions of leading Polish universities for the adequacy of the design and implementation of the BSC. 